\title{
O mesmo, o outro: Psicanálise em movimento ${ }^{1}$
}

\author{
Silvana Rea ${ }^{2}$
}

Bem-vindos!

Em nome da SBPSP eu gostaria de agradecer presença de todos.

E agradecer a presença em nossa casa de Virginia Ungar, presidente da IPA.

"O mesmo, o outro" norteou as atividades científicas desta gestão e foi escolhido como tema geral do nosso I Simpósio.

Pensar as questões de alteridade é uma urgência no século XXI, que se diferencia dos anteriores por suas características próprias. Mas antes de abordá-las, faz-se necessário contextualizar o surgimento da ideia de indivíduo e da identidade individual centrada no eu, que se firma no século XVIII, era da formação dos Estados Nacionais e do liberalismo na economia. E com a noção de eu, surge necessariamente no imaginário a figura do outro. É o momento no qual Daniel Defoe publica o livro Robinson Crusoe e Jonathan Swift lança Viagens de Gulliver; metáforas da aventura em direção ao outro.

Ao final do século XIX e início do XX, a razão iluminista e a identidade fundada na noção de idêntico não se sustentam mais. É quando Freud constrói a Psicanálise, arrastando o outro para dentro; a noção de inconsciente apresenta a inevitável alteridade de nós a nós mesmos. Dividido e múltiplo, o homem da modernidade surge na literatura através dos personagens Frankenstein, de Mary Shelley e O médico e o Monstro, de Robert Louis Stevenson, e mais a frente, Orlando de Virginia Woolf. Sem esquecer de Golyadkin, protagonista do romance $O$ Duplo, de Dostoievsky.

Portanto, para a Psicanálise, quem eu sou sempre se refere a outrem. O início da vida humana e seu processo de subjetivação se dá a partir da presença fundante do outro, mais ou menos

\footnotetext{
${ }^{1}$ Este trabalho é a apresentação da abertura do I Simpósio Bienal "O mesmo, o outro: Psicanálise em movimento" da Sociedade Brasileira de Psicanálise de São Paulo.

${ }^{2}$ Diretora Científica da Sociedade Brasileira de Psicanálise de São Paulo, Doutora em Psicologia da Arte pelo Instituto de Psicologia da USP.
} 
traumática. O conceito de identificação, a primeira experiência de enlace afetivo com outra pessoa, descreve um modo fundamental por onde o outro comparece em nós, nós no outro. Sem esquecer da importância do diferente no cenário edípico, da presença do pai como o forasteiro que chega para a configuração do terceiro.

Sobre as questões de alteridade no século XXI, Noam Chomsky, em Réquiem para o sonho americano, nos alerta que $70 \%$ da população do mundo capitalista não tem como influenciar os rumos da política e tem consciência disso. Incapazes de fazer algo construtivo e sem potência, as pessoas se organizam em direções autodestrutivas: uma raiva sem foco definido que faz com que elas se ataquem umas as outras e ataquem alvos vulneráveis. O objetivo é a corrosão das relações sociais de solidariedade, fazendo com que as pessoas temam e odeiem umas as outras. Enquanto o governo e as grandes corporações concentram a riqueza e as decisões, a sociedade se divide com hostilidade em eu/outro, nós/eles.

É o que observamos no mundo de forma geral, em momento de ódio ao diferente e de recusa à alteridade. Mas, parece, lutamos contra o inimigo equivocado.

Pensando em todas estas questões, idealizamos o I Simpósio Bienal da SBPSP como a série Seeds of Change de Maria Thereza Alves, artista plástica brasileira radicada em Berlim. Um trabalho elaborado a partir do projeto do botânico finlandês Heli Jutila, que desenvolveu um método para localizar e identificar a germinação de sementes presentes no lastro de navios, em diferentes solos.

Explico melhor: em suas viagens, os navios saem carregados e para não retornar vazios, buscam materiais como pedras, terra, areia, tijolos, que são utilizados como peso para oferecer estabilidade - o lastro. De volta a seu porto de origem, a embarcação o deposita em terra firme. Essa necessidade por carga de retorno iniciou uma troca transoceânica de carregamentos, que deixam marcas e constroem uma geografia inusitada. Atenta a isso, Thereza dedica-se a escavar cidades portuárias pelo mundo para pesquisar a flora que resultou das sementes dos lastros descartados.

Em Dubai, Thereza observou que a semeadura não se restringe ao movimento dos portos. As dunas de areia sobre as quais a cidade foi construída movimentam-se constantemente pela ação do vento, que traz sementes do Irã, do Paquistão, da Síria. Resulta desta pesquisa uma 
exposição na qual, entre outras obras, notamos um jardim de espécies não nativas, mas que já são consideradas vegetação da Dubai atual.

Escavando Nova Iorque, a artista descobre que o leste de Manhattan ergueu-se sobre escombros de Bristol, cidade destruída por bombardeios da Segunda Guerra. A região é fruto da troca que envolve, na ida, o envio de armamentos americanos à Inglaterra, e no retorno, o entulho da cidade inglesa como lastro. O Upper East Side, por sua vez, revela resíduos do lastro de navios negreiros, com sementes da Argélia e Moçambique, que nesta zona temperada geraram uma flora tropical surpreendente.

O trabalho de Maria Thereza Alves surge como associação ao tema geral desenvolvido por nossa gestão: "O mesmo, o outro". A ideia de que cidades são construídas a partir de alteridades muitas vezes radicais e que processos identitários nacionais são assentados sobre solo parcialmente estrangeiro, remete-nos à diversidade da vida societária, cheia de energia produtiva; um organismo único construído a partir das mais diferentes sementes, de origens distantes e diversificadas. Esta troca de sementes que se transforma continuamente em novas paisagens, a partir de dentro da Sociedade Brasileira de Psicanálise de São Paulo e em sua relação porosa com outras instituições, nos encaminhou à organização do I Simpósio Bienal da SBPSP "O mesmo, o outro - Psicanálise em Movimento", uma iniciativa primeira de dar voz à unidade feita de alteridades. O trabalho que realizamos foi árduo e elaborado com muito carinho e competência pela comissão organizadora.

Para finalizar, gostaria de retomar o livro A conquista da América, de Todorov. Afinal, contamos hoje com a presença de Virginia Ungar, presidente da IPA e cidadã latinoamericana.

Neste livro Todorov escolhe como tema a descoberta e conquista da América para falar da descoberta que o eu faz do outro.

$\mathrm{Na}$ verdade, Colombo não descobre a América. Ele encontra a América. Porque para ele, o Novo Mundo não é um campo de conhecimento. Em suas cartas aos reis Fernando e Isabela, o navegador se vale do argumento de autoridade, não o da experiência, ou seja, ele usa a experiência concreta para ilustrar uma verdade que de antemão possui. 
Lembro aqui a cena célebre na qual Colombo, confiante de que estava em um continente, não verifica pela experiência se Cuba seria uma ilha. Mais: à tripulação que descia em terra, imputou a pena de dez mil moedas e de ter a língua cortada a quem dissesse o contrário.

Ou quando ele escuta uma língua estrangeira e se recusa a admitir que seja uma língua, chegando a afirmar aos reis que levaria alguns nativos à Espanha "para que aprendam a falar".

Colombo não apenas olha para a nova terra com olhar eurocêntrico - ele desconsidera o outro como subjetividade. Recusa a humanidade, que relutantemente aceita em via tangente: "Apesar de nus" diz ele, "os nativos parecem mais próximos dos homens do que dos animais".

Que risco aos psicanalistas em seu exercício. De se furtar à experiência de receber o outro, de negar a Psicanálise em sua vocação de liberdade e de abertura à alteridade. 